\title{
The Characteristics of Mangrove Species Are Based on Water Conditions in Karimunjawa Nasional Park
}

\author{
Nirwan Niagara ${ }^{1 *}$, Muhammad Yusuf ${ }^{2}$, and Fuad Muhammad ${ }^{3}$ \\ ${ }^{1}$ Department of Environmental Science, Faculty of School of Postgraduate Studies, Universitas \\ Diponegoro, Indonesia. \\ ${ }^{2}$ Department of Marine Sciene, Faculty Fisheries and Marine Sciene, Universitas Diponegoro, \\ Indonesia. \\ ${ }^{3}$ Department of Biology, Faculty of Science and Mathematics, Universitas Diponegoro, Indonesia.
}

\begin{abstract}
The mangrove ecosystem in Karimunjawa National Park has an area of 222.2 hectares of mangrove, which functions as a habitat for various types of biota. The condition of the waters will determine the future of the mangrove ecosystem. It aims to identify the characteristics of mangrove species based on the conditions of Karimunjawa waters. The method used is a journal literature review. There are several journals about the characteristics and conditions of different mangroves. The results of this study various mangrove ecosystems can live in the waters of Karimunjawa. Based on the results of the study during the literature review, there are 9 types of mangroves in Karimunjawa, namely: Cerriops tagal, Lumnitzera racemosa, Rhizophora apicullata, Rhizophora stylosa, Sonneratia caseolaris, Excoracia agalloca, Rhizophora mucronata, Scyphilappuphoranata and Xcyphillappuburanata, which can survive on 3 substrates, rocky ground, sand. Mangroves can grow in shallow water ecosystems because the shape of their roots can help adapt to the aquatic environment. Mangroves can live in salty or brackish areas ranging from $11-25 \%$. It was concluded that the type of substrate and water conditions affect mangroves to live in harmony.
\end{abstract}

\section{Introduction}

Karimunjawa National Park covers 22 of the 27 islands in the Karimunjawa Archipelago. Five of the islands are inhabited by residents. As a conservation area that has very potential natural resources and high biodiversity. Karimunjawa National Park, located in Jepara Regency, Central Java, represents the integrity of the north coast ecosystem of Java. As the main management element, the zoning of Karimunjawa National Park has undergone two revisions in 2005 and 2010. Karimunjawa is divided into five ecosystem types: tropical rain forest, lowland, coastal forest, mangrove forest, seagrass ecosystem and coral reef ecosystem.

\footnotetext{
* Corresponding author: niagaranirwan96@gmail.com
} 
One type of ecosystem in the Karimunjawa National Park is a mangrove ecosystem. More than one type of mangrove grows and lives in the mangrove ecosystem of Karimunjawa National Park. The types of mangroves found in the mangrove ecosystem of Karimunjawa National Park need to be identified one by one. The identification process can be viewed in terms of the morphology of the mangrove parts. By knowing the types of mangroves that exist, we will know the benefits for the surrounding environment.

It is necessary to identify the types of mangroves along the tracking area of mangroves; this is to determine the distribution of species along the tracking area to provide knowledge about mangrove species in terms of mangrove morphology.

\section{Literature Review}

\subsection{Mangrove}

Mangroves are various supporting plants types of coastal ecosystems, river estuaries and deltas in tropical and sub-tropical areas. One of the characteristics of the mangrove plant is that it has roots that stick out to its surface. The appearance of mangroves is like a stretch of thicket separating the land from the sea so that mangroves can be said to be ecosystems transition between land and sea. Mangroves are also commonly known as plants mangroves [1].

Mangroves are typical plants of the tropics whose life is only well developed at temperatures from $19^{\circ} \mathrm{C}$ to $40^{\circ} \mathrm{C}$ with a fluctuation tolerance of not more than $10^{\circ} \mathrm{C}$. Various types of Mangroves grow on the shoreline and encroach to grow to jut into the watery zone of the sea, is a unique ecosystem. Typical because it survives in two zones4 transitions between land and sea, while other plants are unable to survive [2].

Based on the results of the review during the literature review search, there were nine mangrove species along with the Karimunjawa National Park Mangrove Tracking, namely: Cerriops tagal, Lumnitzera racemosa, Rhizophora apicullata, Rhizophora stylosa, Sonneratia caseolaris, Excoracia agalloca, Rhizophora mucronata, Scyphiphora hydrophyllaea and Xylocarpus moluccensis.

\subsection{Mangrove Ecosystem}

Natural resources that play an essential role in the coastal area are mangrove forests, which are good at maintaining coastal productivity waters and supporting the life of the surrounding community. For coastal areas, mangrove forests, especially as a green lane along the coast, are very important in maintaining the quality of the ecosystem fisheries, agriculture, and the settlements behind it [3].

Mangrove forest ecosystems include coastal ecosystems or exciting shallow marine communities found in tropical waters and subtropics. Research on mangrove forests is mainly done in other coastal ecosystems. Mangrove forests are more ecosystem specific when compared to other ecosystems because it has vegetation that is somewhat uniform and has a flat canopy. The interacting ecosystem components influence the structure and composition of vegetation. An area's vegetation that grows naturally reflects the results of the interaction of various environmental factors [1]. 


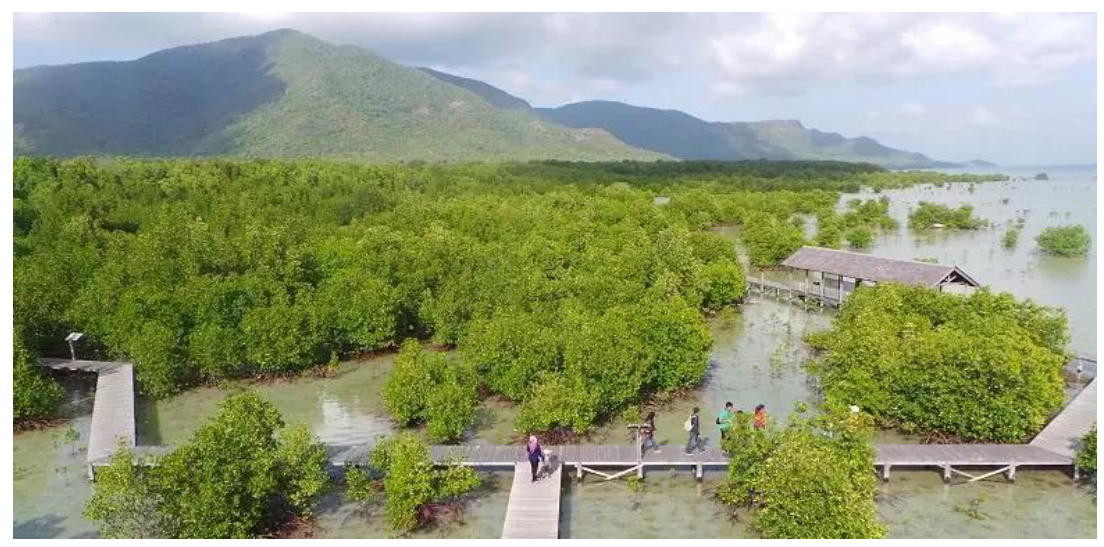

Fig. 1. Magrove ecosystem in Karimunjawa Nasional Park.

\subsection{Benefits or Functions of Mangroves}

The presence of mangroves on the coast is essential as a habitat for fishery fauna, physical protection for the coastline, spawning, nursery and feeding ground. Limited area of land and resources inland and the increasing population, there are many development activities diverted from land to coast and oceans to economic enhancement income and community welfare through development fishpond cultivation, fishing gear, ports, processing industry and tourism. Sectoral management of mangrove areas maximizing production without considering the limitations of carrying capacity and the carrying capacity of the environment and the limited capacity of its assimilation capacity will trigger environmental degradation and decrease natural resources itself [5].

The mangrove ecosystem has the ability to absorb and store carbon. The mangrove ecosystem is one coastal ecosystem that is under great anthropogenic stress. Functional shift mangrove land becomes cultivation land or other purposes shows a trend getting more significant from year to year. Mangroves have several functions, including, namely: a place for land development, deposition mud, fauna habitat, especially marine fauna, agricultural land and salt ponds, protect coastal ecosystems globally, the beauty of landscapes, places education and training. Based on several existing functions, it can be said mangroves are very beneficial for the surrounding community, the wider community and fauna 5 the sea. The benefit for the wider community here is the information obtained about the types of mangroves that exist in that place and how much information the importance of the mangrove ecosystem in their place [6].

\subsection{Mangrove Environmental Parameters}

Water quality is very much determined by various natural processes and anthropogenic influences. Various inputs that go into water bodies due to human activities impact natural ecosystems waters in the form of physical, chemical, and biological processes and causes changes in water quality conditions. There are water quality standard criteria that various national and international institutions have established. Conventional assessment of water quality parameters is to compare values measurement results with a predetermined standard or quality standard. It is known that it does not fully inform the overall development of water quality spatially or temporally. Although modelling mathematically is the best approach for determining trends in quality conditions waters, but in this case, a more significant effort is required; the cost is sufficiently high, special skills, and not easy to apply [7]. 
The mangrove ecosystem is a system that consists of organisms (animals, plants, microbes) that interacts with environmental factors in a mangrove habitat. Ecosystem environment mangroves will include various factors such as biotic factors and abiotic factors. Abiotic factors can include chemical factors and physical environmental factors, such as $\mathrm{pH}, \mathrm{DO}$, salinity, temperature, and others [8].

\section{Research Methods}

The method used is a journal literature review. There are several journals about the characteristics of mangroves that come from different mangrove conditions, mangrove types and identifying them in terms of mangrove morphology, identification of mangrove substrates.

\section{Result and discussion}

Some of the potentials that exist in Karimunjawa National Park are high biodiversity, especially in the coral reef environment, mangroves and seagrass. An area that has natural beauty with its state pristine and beautiful forests, white sand on the beaches with coral reefs surrounding each island, the endemic dewandaru tree, the bird Hawks, Red clams, Green turtles, Hawksbill turtles and Lekang turtles. Potency high resources both marine tourism and environmental tourism and recreation aimed at national and international scales [9]. Based on the results of the review during the literature review search, there were 9 mangrove species along with the Karimunjawa National Park Mangrove Tracking, namely: Cerriops tagal, Lumnitzera racemosa, Rhizophora apicullata, Rhizophora stylosa, Sonneratia caseolaris, Excoracia agalloca, Rhizophora mucronata, Scyphiphora hydrophyllaea and Xylocarpus moluccensis.

\section{1) Cerriops tagal}

Local names Tengar, Tengah, Tangar, Tingih, Tingi, Palun, Parun, BidoBido, Lonro, Mentigi, Tengar, Tinci, Mange Darat, Wanggo. A small tree or shrub up to $25 \mathrm{~m}$ tall. Skin wood is grey, sometimes brown, smooth, and the base is bulging. Trees often have roots that support the little one. The leaves are shiny green and often have a fringe circular inward. Unit \& Layout: simple \& opposite. Shape: inverted-ellipse ovoid. Edge: rounded. Size: 1- 10 x 2$3.5 \mathrm{~cm}$. Flowers clustered at the end of the bunch. Long flower handle and thin berries at the end of a new branch or on the armpit of a branch older. Location: in the axilla. Formation: groups (5-10 flowers per group). Corolla: 5; white and then brown. Flower petals: 5; green colour, length $45 \mathrm{~mm}$, tube $2 \mathrm{~mm}$. Stamens: stamens longer than the anthers that are blunt. Fruit 1.5-2 cm long, with a tube of petals curved. Hypocotyl patches, smooth-skinned, slightly bulging and often a little short. Cotillon neck turn yellow when it is ripe/mature. Size: Hypocot: 4-25 cm long and 8-12 $\mathrm{mm}$ in diameter. Forms dense thicket on the land edge of the forest tides and areas inundated by high tides with the soil having a good drying system. Also found along the pond. Liked the clay substrate and the possibilities side by side with Cerriops decandra. Inflorescence occurs throughout the year. 


\section{2) Excoracia agalloca}

Local names Buta-Buta, Menengan, Madengan, Kayu Wuta, Sambuta, Kalapinrang, Mata Huli, Makasuta, Goro-Goro Raci, Kalibuda, Betuh, Warejit, Bebutah. A small deciduous tree up to $15 \mathrm{~m}$ in height. Skin the wood is grey, smooth but has a nodule. The roots spread along the soil surface; it is often tangled and covered by lenticels. Stems, branches and leaves have sap (white and sticky) which can irritate the skin and eyes. Dark green and will turn brick red before falling off, a finely serrated edge. There are 2 glands at the base of the leaf. Unit \& Location: simple, crossed. Shape: an ellipse. Edge: tapered. Size: 6.5-10.5 x 3.5-5 cm. Has male or female flowers only, never both. The male flowers (without peduncles) are smaller than the female and spread out along the bunch. The male flower bunches smell scattered, green and up to $11 \mathrm{~cm}$ long. Location: in the armpit leaf. Formation: grain. Corolla: green and white. Petals flower: yellowish-green. Stamens: 3; yellow. Ball-like shape with 3 protrusions, green colour, surface like skin, contains dark brown seeds. Size: diameter 5$7 \mathrm{~mm}$. This plant requires an input of freshwater throughout the year in large quantities. It is generally found on the edge mangroves on land, or sometimes above the water level, plug it in. This species is also found growing along the edges of a salt lake ( $90 \%$ seawater) on the volcanic island of Satonda, to the north of Sumbawa. They are commonly found as grown in several logged forests, for example, in WIldlife reserve. Karang-Gading Langkat Northeast, close Medan, North Sumatra. Inflorescence occurs throughout the year. Insects, especially bees, carry out pollination. This is 19 mainly thought to occur due to the presence of thick pollen and nectar, which produces glands at the tip of the pinak leaves under the flower.

\section{3) Lumnitzera racemosa}

Local names Api-Api Balah, Susup, Lasi, Male Sitting, Api-Api Guava, Teruntum, Aduadu, Sitting, Knias, Saman-Sigi, Kedukduk, Guided. Thick grove or small tree, evergreen with a height of reaching $8 \mathrm{~m}$. The bark is reddish-brown in colour, has cracks/cracks longitudinal (especially in old stems), and does not have a root of breath. The leaves are slightly thick fleshy, hard/stiff, and clumps at the top limb. The length of the petiole reaches $10 \mathrm{~mm}$. Unit \& Location: simple, cross over. Shape: oval narrow. End: round. Size: $2-10$ x 1-2.5 cm. Bisexual flowers, without peduncles, bright white, filled with nectar. Bunch length 1-2 cm. It has two pinak shaped leaves ovate, $1.5 \mathrm{~mm}$ long at the base. Location: on the tip or in the armpit. Formation: grain. Corolla: 5; white, $2-4$ x 7-8 mm. Flower petals: 5; green $(6-8 \mathrm{~mm})$. Stamens: $<10$; The length of the stamens is the same or slightly longer than the leaves crown. Fruit: Fruit in the form of flatulence/ellipse, yellowish-green, fibrous, woody and dense. Size: 7-12 mm long; Diameter 3-5 mm. Grows along the edges of mangrove vegetation. Liked the substrate solid muddy. They also exist along the waterway affected by freshwater. White flowers, slightly fragrant and rich in nectar, are pollinated by insects. Fibrous fruit adapted for spread through water.

\section{4) Rhizhophora mucronata}

Local names Bangka Itam, Dongoh Korap, Black Mangrove, Korap Mangrove, Mangrove Merah, Jankar, Lenggayong, Belukap, Lolaro. Tree up to $27 \mathrm{~m}$ in height, rarely exceeding 30 $\mathrm{m}$. The trunk has a diameter of up to $70 \mathrm{~cm}$ with coloured bark dark to black, and there is a horizontal gap. Supporting roots and aerial roots growing from the lower parting. Leaf skin. Leaf handles are green, $2.5-5.5 \mathrm{~cm}$ long. Pinak leaves are located at the base of the leaf stalk, measuring 5.5-8.5 cm. Unit \& Layout: simple \& opposite. Shape: wide ellipse until round elongated. Edge: tapered. Size: $11-23$ x $5-13 \mathrm{~cm}$. The forked, bisexual flower head handles are attached to an individual handle $2.5-5 \mathrm{~cm}$ long. Location: in the axilla. Formation: Groups (4-8 flowers per group). Corolla: 4; white, no hair. $9 \mathrm{~mm}$. Petals flowers: 4; pale yellow, 13$19 \mathrm{~mm}$ long. Stamens: 8; not stemmed. Fruit oval / long to egg-shaped measuring 5-7 cm, greenish-brown in colour, often rough at the base, seeded single. Hypocotyl cylindrical, 
coarse and grainy. Cotillodon neck yellow when ripe. Size: Hipocot: length 36-70 cm and 2$3 \mathrm{~cm}$ in diameter. In the same area as R.apiculata but more tolerant of harder substrate and grit. Generally grows deep groups, near or on tidal stream embankments and at estuaries, rarely grow in areas far from water ups and down. Optimal growth occurs in an area inundated, as well as in humus-rich soils. Is one of the most important types of mangrove plants and most widespread. Inflorescence occurs throughout the year. The chicks are often eaten by crabs, thus inhibiting their growth. Tillers that have been dried below shade for several days will be more resistant to disturbance crab. This may be due to the accumulation of tannins in the network, which then protects them.

\section{5) Rhizophora apicullata}

Local names Oil Mangrove, Tandok Mangrove, Akik Mangrove, Puteh Mangrove, Peanut Mangrove, Leutik Mangrove, Agate, Bangka Minyak, Donggo Akit, Jankar, Abat, Parai, Mangi-Mangi, Slengkreng, Tinjang, Wako. A tree up to $30 \mathrm{~m}$ in height in trunk diameter reaches $50 \mathrm{~cm}$. It has a distinctive root to reach a height of 5 meters and sometimes has its aerial roots out of the branch. The bark is dark grey and changing. Skin, dark green colour with light green in the middle and redness at the bottom. Leaf handle is 17-35 length mm, and the colour is reddish. Unit \& Layout: simple \& opposite. Shape: a narrowed ellipse. Edge: tapered. Size: $7-19 \times 3.5-8 \mathrm{~cm}$. Bisexual, yellowish flower heads located on the peduncle $<14$ $\mathrm{mm}$ in size. Location: In the axillary leaves. Formation: group ( 2 interests per group). Corolla: 4; yellow-white, nothing hair, 9-11 mm long. Flower petals: 4; yellow-brownish, curved. Stamens: stemless. The fruit is roughly round and elongated like a pear, brown, 2$3.5 \mathrm{~cm}$ long, contains one fertile seed. Hypocotyl cylindrical, nodule, orange green. The neck of the cotillodon is coloured red when ripe. Size: Hipocot length $18-38 \mathrm{~cm}$ and $1-2 \mathrm{~cm}$ in diameter. It grows on muddy, smooth, deep and stagnant soil at times normal tide. Dislikes tougher substrates mixed with sand. The domination rate can reach $90 \%$ of vegetation growing in a location. Liked the tide low tide, which has a strong freshwater input effect permanent. Root branches can grow abnormally because of the disturbance of the beetles that attack the root tips. Crab can also stunt their growth by being annoying root bark of tillers. Slow growing, but there are inflorescences throughout the year.

\section{6) Rhizophora stylosa}

Local names Bakau, Bako-Kurap, Slindur, Tongke Besar, Wako, Bangko. A tree with one or many trunks, up to $10 \mathrm{~m}$ high. Skin smooth wood, slit, grey to black. Has roots supports up to $3 \mathrm{~m}$ long and sprouting aerial roots from the lower branch. Leaves skinned, regularly spotted on the undercoat. Leaf handle green, handle 1-3.5 cm long, with pinak leaves $4-6 \mathrm{~cm}$ long. Unit \& Layout: simple \& opposite. Form: a dilated ellipse. Edge: tapered. Size: tapered. Handles of flower heads such as fork, bisexual, respectively attached to individual handle 2.5-5 cm long. Location: in the axillary of the leaves. Formation: groups (8-16 flowers per group). Corolla: 4; white, there is hair. $8 \mathrm{~mm}$. Flower petals: 4; yellow-green, 13-19 mm long. Stamens: 8; and a pistil, 4-6 mm long. A Fruit 2.5-4 cm long, pear-shaped, brown, contains 1 seed fertile. Hypocotyl cylindrical, slightly fine nodules. Cotillodon neck greenish-yellow when ripe. Size: Hipocot: length $20-35 \mathrm{~cm}$ (sometimes up to $50 \mathrm{~cm}$ ) and $1.5-2.0 \mathrm{~cm}$ in diameter. Grows in a variety of habitats in tidal areas: mud, sand and rock. Likes tidal river embankments and is a type of pioneer in the coastal environment or on the land part of the mangrove. One typical niche type that can it occupies is the edge of the mangrove on the island/coral substrate. Produces flowers and fruit all year round. Possibility pollinated by the wind. 


\section{7) Scyphiphora hydrophyllacea}

Local names Perepat Lanang, Cingam, Sitting Women, Sitting Termites, Sit Creep, And Skin. The shrub is upright, evergreen, often has many branches, the height reaches $3 \mathrm{~m}$. Brown leathery bark, branches young have resin, sometimes there are root supports on the great individual. Leaves skinned and shiny. Pinak leaves with glands located on the base of the leaf handle form a hairy cap. Leaf handle straight length up to $13 \mathrm{~mm}$. Unit \& Layout: simple \& opposite. Shape: inverted ovoid. Edge: rounded. Size: $4-9$ x $2-5 \mathrm{~cm}$. White flower, almost stemless, bisexual in colour bunches up to $15 \mathrm{~mm}$ long. Location: in the axilla. Formation: groups (3-7 flowers per group). Corolla: 4-5; white-slightly red, elliptical, 2-4 x $22.5 \mathrm{~mm}$, mouth with coarse hair. Flower petals: 4-5; bowl-shaped, the bottom is like a tube (length $5 \mathrm{~mm})$. Stamens: 4-5. Cylindrical fruit, green to brown, veined and elongated, has the rest of the petals. It does not open when ripe. There are 4 cylindrical seeds. Size: fruit: $8 \mathrm{~mm}$ long, seeds: 1 × $2 \mathrm{~mm}$. Grows on the substrate of mud, sand and coral on the edge of the land mangroves or embankments and near waterways. Not tolerant of a long time standing fresh water and usually occupies a location often inundated by tides receding. Reported growing in locations unsuitable for colonisation by other mangrove plant species. Inflorescences are Available throughout the year, possibly self-pollinated or by an insect. Glandular discs produce nectar at the base flower Crown. Much fruit was produced, however relatively low seed breeding. Fruit well adapted to spread by water due to the light skin of the fruit and float.

\section{8) Sonneratia caseolaris}

Local names Pedada, Perepat, Pidada, Bogem, Bidada, Rambai, Wahat Red, Posi-Posi Red. Tree, up to $15 \mathrm{~m}$ high, rarely up to $20 \mathrm{~m}$. Has vertical breath roots like a cone (up to $1 \mathrm{~m}$ high) which is many and very strong. The ends of branches/twigs droop and are rectangular when young. Reddish hilt/petiole, wide and very short. Unit \& Location: simple \& opposite. Shape: round elongated. End: round. Size: varies, 5-13 x 2-5 cm. The flower buds are ovoid. When in full bloom, tube petals flower-shaped bowl, usually without veins. Location: at the end. Formation: solitary group (1-3 flowers per group). Leaf crown: red, size 17-35 x 1.5-3.5 $\mathrm{mm}$, easy to fall off. Flower petals: 6-8; skinned, outside green, inside white-yellowish to greenish. Stamens: many, white tips and the base is red, easy to fall off. A Fruit Like a ball, the ends are stemmed, and the bottom is wrapped in flower petals. Larger size than S.alba, more seeds (800-1200). Size: fruit: 6-8 cm diameter. Grows in less salty parts of mangrove forests, on the ground deep mud, often along small streams with water which flows slowly and is affected by the tides - not ever grown on embankments / rocky areas. It also grows along the river, starting from the headwaters where the tide influences receding is still felt and in areas that are still dominated by water bargains. Not tolerant of shade. When flowers bloom full (after 8:00 p.m.), flowers contain much nectar. Inflorescence occurs throughout the year. Seeds float. During the rain bushy, the tendency for leaf growth will change from horizontal to vertical.

\section{9) Xylocarpus moluccensis}

Local names Niri / Nyirih Batu, Nyirih, Siri, Jombok, Miumeri-Mee, Parasar, Kabau, Raru, Nyiri Mistress, Nyuru, Mojong Tihulu, Pamuli, Loleso, Banang-Banang. The tree is between 5-20 $\mathrm{m}$ high. Has the root of the breath pursed in the shape of a cup. The bark is smooth, while the main trunk has deep scratched surface scratches. Thinner than X.granatum, leaf arrangement in pairs (generally 2-3 ps stem) and some are alone. Unit \& location: compound $\&$ opposite. Shape: ellipse - inverted ovoid. End: tapered. Size: $4-12 \mathrm{~cm}$ x 2-6,5cm. It consists of two genders or only females. Bunches of flowers $(6-18.5 \mathrm{~cm}$ long) arise from the axillary petiole and stalk flowers $2-10 \mathrm{~mm}$ long. Location: in the armpit. Formation: hordes random (10-35 flowers per bunch). Corolla: 4; white, yellowish, oval, rounded edges, 6-7 mm long. Petals flowers: 4 lobes; yellowish-green, about $1.5 \mathrm{~mm}$ long. Yarn sari: 8 , unite; creamy white 
and about $2 \mathrm{~mm}$ high. Fruit: Green, round like a Bangkok guava, skinned surface and in it there are 4-10 pieces of tetrahedral seed. Size: fruit: diameter $8-15 \mathrm{~cm}$. The true mangrove species in tidal forests, river embankments, tides, and looks along the coast.

Based on the results from journal observations, the substrate, located in Karimunjawa National Park, consists of 3 types of substrates, namely loose soil, soil craggy, seawater sand. Species These mangroves can grow well in shallow water ecosystems because of the form of roots that can help to adapt to the aquatic environment, both from the influence of tides and factors - other environmental factors that affect the mangrove ecosystem such as temperature, salinity, dissolved oxygen, sediment, $\mathrm{pH}, \mathrm{Eh}$, currents and waves [10]. In general, mangroves live in salty or brackish areas ranging from 11-25\%. Salinity is an essential factor in the growth, endurance and zoning of mangrove species [11].

\section{Conclusion}

The types of mangroves found in the Park Karimunjawa National there are 9 types, namely: Cerriops tagal, Lumnitzera racemosa, Rhizophora apicullata, Rhizophora stylosa, Sonneratia caseolaris, Excoracia agalloca, Rhizophora mucronata, Scyphiphora hydrophyllaea and Xylocarpus moluccensis.

Mangrove forests can live and grow in 3 types of substrates, namely loose soils, rocky soils, and sea sand. Species These mangroves can grow well in shallow water ecosystems because of the form of roots that can help to adapt to the aquatic environment, both from the influence of tides and factors - other environmental factors that affect the mangrove ecosystem such as temperature, salinity, dissolved oxygen, sediment, $\mathrm{pH}, \mathrm{Eh}$, currents and waves. In general, mangroves live in salty or brackish areas ranging from 11-25\%. Salinity is an essential factor in the growth, endurance and zoning of mangrove species.

\section{References}

1. Susilo, Analysis of mangrove vegetation (Rhizophora) on the coast of Menjangan Besar Island, Karimunjawa. Biomedical Journal, 10(2), 58-68 (2017)

2. A. A. Idrus, M. L. Ilhamdi, G. Hadiprayitno, G. Mertha, Socialization of the Role and Function of Mangroves in Communities in the Gili Sulat Area, East Lombok. Journal of Magister Service in Science Education, 1(1), 52-59 (2018)

3. S. Handayani, Identification of mangrove plants as food alternative in Sidoarjo Regency, East Java. Journal of Food Technology, 12(2), 33-46 (2018)

4. Y. R. Buwono, Identification and density of mangrove ecosystems in the area Pangpang Bay, Banyuwangi Regency, Journal of Fisheries Sciences, 8(1), 32-37 (2017)

5. T. L. Kepel, R. N. A. Ati, Y. P. Rahayu, N. S. Adi, Effect of function transfer mangrove area on sediment properties and carbon storage capacity, National Oceanic Journal, 13(3), 145-153 (2018)

6. R. H. Prastomo, R. Herawatiningsih, S. Latifah, Diversity vegetation in the mangrove forest area of Nusapati Village, Mempawah Regency, Sustainable Forest Journal, 5(2), 556-562 (2017)

7. I. K. Ginantra, A. A. K. Darmadi, I. B. M. Suaskara, I. K. Muksin, The diversity of mangrove types on the coast of Lembongan in support mangrove tour activities, Journal of National Seminar Proceedings Biology Education, 2(8), 249-255(2018) 
8. R. Sulisyati, P. Puji, Mulyadi, Revised zoning of the National Park Karimunjawa as a compromise in natural resource management, Journal of the National Geomatics Seminar, 713-724 (2018)

9. W. Giesen, Indonesia's mangroves: An update on remaining areas and main management issues, In the Seminar on Coastal Zone Management of Small Island Ecosystems, 10 (1993)

10. Y. R. Noor, M. Khazali, I. N. N. Suryadiputra, Introduction guide mangroves in Indonesia, 2(220), (2006) 